FACTA UNIVERSITATIS

Series: Teaching, Learning and Teacher Education Vol. 4, $\mathrm{N}^{\mathrm{o}} 1$, 2020, pp. 1 - 16

https://doi.org/10.22190/FUTLTE2001001S

Original research paper

\title{
THE EXPRESSION OF ADVERBIAL QUALIFICATON IN THE SPEECH OF PRESCHOOL AND ELEMENTARY SCHOOL CHILDREN FROM VRANJE
}

\author{
UDC 811.163.41'366.54; 811.163.41'27'282.3

\section{Dragana Stanković} \\ Pedagogical Faculty in Vranje, University of Niš, Serbia
}

\begin{abstract}
This paper analyses the case constructions that preschool and elementary school children from Vranje use to express adverbial qualification. The aim of this paper is to determine which case forms preschool and elementary school children from Vranje use to express the category of adverbial qualification and in which case structures standard language case form enters most easily. The speech of 40 examinees of different age, sex, place of residence, parents' education was analyzed. The material was collected by the method of spontaneous conversation. All recorded case forms are analyzed and described by the descriptive method. The most stable analytical form are determined by the percentage analysis. The conducted analysis showed that preschool and elementary school children from Vranje express the meaning of adverbial qualification by the analytical constructions in function of genitives, accusatives, instrumentals and locatives. They are used to express the meaning of instrumentation, meditatively, comitivity, criteria, distributivity and comparatively. However, under the influence of standard language, the infiltration of flective form was recorded. The standard case form influences most intensively on the analytic construction in the function of the genitive. On the other hand, the construction in the function of locative is more resistant to the influence of linguistic standard. Considering that the study of the dialect syntax of cases and the speech of children is rarity in dialectological researches, the conducted research is justified and important for further researches in this field and for the teaching of Serbian grammar in Prizren-Timok speaking area.
\end{abstract}

Key words: adverbial qualification, speech of children from Vranje, declension, analytism, standard linguistic case form.

Received May 8, 2020/Accepted June 19, 2020

Corresponding author: Dragana Stanković

Pedagogical Faculty in Vranje, University of Niš, Partizanska 14, 17500 Vranje, Serbia

Phone: +381 17422 962•E-mail: gagat79@gmail.com 


\section{INTRODUCTION}

Analytism is the basic characteristic of noun declension of Prizren-Timok speech region. This Balkan phenomenon in the morphological system implies the infiltration of one case form into the significance of other cases and the strengthening of prepositional constructions in which the case meaning is transferred to the preposition. In shapes, the general case (opšti padež) is equal to the accusative and differ from the nominative only in nouns of singular masculine gender ending in a consonant denoting the living thing and the nouns of feminine gender ending in $-a$. In other nouns, the nouns of masculine gender denoting non-living thing, in the nouns of neuter gender, in the nouns of feminine gender ending in a consonant, and in the plural of all nouns, the general case is equal to the nominative case. ${ }^{1}$ From a syntactic point of view, analytical structure (a proposition + general case) can express all the meanings that the preposition-case constructions have in the flective system. Z. Topolinjska the category of the case "rises from morphological to morph syntactic level" (2002, p. 1). By the term of case she implies "syntactic relationship between the nominal phrase and the linguistic construction (morph syntactic unit) from which this phrase is grammatically dependent" (Ibid). In this sense, the general case is a syncretic nominal form that enters into various case relations (Ibid, p. 10).

The dialect syntax of cases is the least studied field in the research of Prizren-Timok speech region. Monographs on Prizren-Timok speeches give a detailed description of the features on the phonetic-phonological and morphological level, while the data on the syntax of cases is given by the side. However, significant works of this field appeared in dialect literature. An important study on the dialect syntax of cases is the study of the genitive meanings in the Jablanica speech Expression of the genitive meanings in the speech of the Jablanica region (in the light of Prizren-Timok speeches as a whole) by $\mathrm{R}$. Žugić (2010). The study in general dedicated to the case syntax of one speech of PrizrenTimok speech region is The Case syntax of Gornja Pčinja (Specified functions) by M. Jurišić (2014). Several papers by A. Mladenović deal with the case meaning in the declension system of South-Metohija and Northern-Šarmountain speeches (Mladenović $1997,2002,2004,2012,2013,2014)$. A. Sobolev wrote about the case relation in PrizrenTimok region and beyond (1988, 1990, 1991a, 1991b). Z. Topolinjska (2001) gives an analysis of the material from Prizren speech, based on the so-called anthropocentric theory of the case relation.

Bearing in mind that the case represents a morph syntactic category, the category of syntactic relations, and not morphological forms (Topolinjska, 2002), the meaning of case represents the starting point of declension of one speech study, and so the subject of this paper is one of the many case meanings - the meaning of adverbial qualification. Adverbial qualification implies a semantic category which in traditional syntax signifies the way in which a verbal action is performed. In The Syntax of Contemporary Serbian Language (Piper, P. et cet. 2005) the qualification of quality and qualification of manner are discussed: "In the meaning of manner as qualification of a certain action, there is a process moment as a notion of quality which is realized through the given action, i.e. manner is abstractly understood path of a process or state realization"(Ibid, p. 839). This semantic category in Serbian language is expressed by a variety of language tools - by

\footnotetext{
${ }^{1}$ Considering the analytism of Prizren-Timok speeches, A. Belić introduces terms casus rectus and casus obliquus, when the accusative case, i.e. the general case is not equal to the nominative case, and casus generalis, when the general case is equal to the nominative $(1999$, p. 225).
} 
prepositional-case constructions and case constructions without prepositions, by verbal adverbs, and most often, by adverbs of manner and adverbial phrases (Ibid, p. 839). Expressed by case forms, adverbial determination implies several semantic types: instrumentation, meditatively, comitivity, criterion, distributivity, comparatively (Pavlović, 2006, pp. 194-250; Jurišić, 2014, pp. 466-478).

We decided to research the expression of adverbial qualification in the speech of children from Vranje because up to date researches have shown that the youngest population has the biggest problems in adoption of the standard language norm while adopting the standard language case system (Janjić, 2004, 2005a, 2005b, 2009; Žugić, 2012, 2013; Stanković, 2018).

Most researchers of children's speech believe that speech development ends with the fifth or sixth year, and according to some authors, with the fourth year of a child' life (Ivić, 2008, 35). This actually means that the child has already mastered the basic language structures at the age of about five and achieves real verbal communication. Also, children adopt case forms very early - up to the third year of life (Jocić, 2006, pp. 111-130; KostićVladisavljević, 2008, pp. 133-139). Accordingly, our examinees are children aged 5 to 14 years. In their speech activity all case forms with different case meaning appear, including the meaning of adverbial qualification.

Considering that the study of the dialect syntax of cases and the speech of children is rarity in dialectological researches, the conducted research is justified and important for further researches in this field and for the teaching of Sebian grammar in Prizren-Timok speaking area.

\section{METHOdOLOGICAL FRAMEWORK OF RESEARCH}

The aim of this paper is to determine which case forms preschool and elementary school children from Vranje use to express the category of adverbial qualification. Also, taking into account analytism, which is at the basis of declension of Prizren-Timok speeches, and the penetration of flective form due to the speech exposure to the influence of standard language, we wanted to determine in which case constructions standard language case form enters most easily.

The speech of 40 examinees of different age, sex, place of residence, education of parents was analyzed. As the subject of the survey is urban speech, examinees are children who were born and live in Vranje and whose parents were born and live in Vranje. According to their age, the examinees were divided into three groups - children of preschool age, 5 and 6 years old (16 rexaminees), school age children from first to fourth grade (12 examinees) and school age children from fifth to eighth grade (12 examinees). Within the pre-school age children, one group was consisted of children who attend kindergarten (12 examinees), and the other group was consisted of children who do not attend kindergarten (4 examinees). There were twenty girls and twenty boys. According to the place of residence, one group was consisted of children who live in the city center (20 examinees), and the second group was consisted of children who live on the periphery (20 examinees). According to parents' education, one group was consisted of children whose both parents have Bachelor's degree (12 examinees), the second group was consisted of children whose one parent has Bachelor's degree and the other parent has high school diploma (13 examinees) and third group was consisted of children whose both parents have secondary school diploma (15 examinees). 
The research method is an interview conducted by the examiner. In order to lead the examinees to use as much as possible day to day speech or informal speech, a discussion was held on various topics close to examinees. The examiner tried to achieve as much immediacy as possible and to talk to them on the dialect. The examiner starts the conversation, suggests topics, but allows the examinee to talk about different topics in which examinee is interested in. In addition, the examinees responded directly to the questions, if some important detail was not obtained in the spontaneous conversation, they described the drawings with specific instruction of the examiner in the form of questions by which required language feature is obtained. The youngest examinees also described drawings in the drawing books. The most common topics were: kindergarten / school, friends, games, toys, birthday celebrations, winter and summer holidays, trips, excursions, parents, siblings, grandparents, educators, teachers, pets, school activities, free time, hobbies, (cartoons) movies, music, going out, falling in love, learning. The conversation was conducted at least on two occasions. They talked to each examinee individually, in a special room in the kindergarten or school. Only with children who do not attend to kindergarten the conversation was conducted in a home atmosphere, but without the presence of parents. The recorded conversation lasted from one to two hours with each examinee, i.e. two school classes with children of school age. The conversation was recorded and transcribed.

In the transcribed material, all case constructions with the meaning of adverbial qualification were singled out and analyzed. We determined the following units of analysis: analytical case constructions, standard case constructions and percentage of use of analytical constructions. The descriptive method gives the basic characteristics of the investigated features, analyzes and describes all recorded forms. The most stable analytical form are determined by the percentage analysis.

\section{ANALYSIS OF MATERIAL ${ }^{2}$}

\subsection{Instrumentation}

Instrumentation implies different phenomena "through which the agent performs the action of direct predication including them in a concrete realization as a performer or a facilitator" (Pavlović, 2006, p. 196). ${ }^{3}$ The concepts-instruments can be: parts of bodies (organs), objects, animals, activities or states, weather conditions. In the analyzed speech, the instrumentation is realized mainly by the analytical constructions in function of genitives, accusatives, instrumentals and locatives. Flective form is represented to a lesser degree.

\footnotetext{
${ }^{2}$ Excerpted material in this paper is given according to semantic categories from monograph by S. Pavlović (2006) and M. Jurišić (2014). For each semantic category we obtained large number of examples, however, due to spatial restriction, we illustrated the recorded case structures with one example which is glossed in accordance with The Leipzig Glossing Rules. The following abbreviations are used in glossing text: 1 - first person, 2 - second person, 3 - third person, ACC - accusative, ACC/GC - general case = standard accusative, ADV - adverb, AUX - auxilliary, F feminine, FUT - future, GC - general case, GEN - genitive, INS - instrumental, LOC - locative, M - masculine, NEG negation, NOM - nominative, NUM - number, PL - plural, PREP - preposition, PRON - pronoun, PRS - present, PST past, REFL- reflexive, SG - singular.

$\mathrm{M}$. Ivić distinguishes two functions of the instrumental category of the means - the function of the conductor and the facilitator. The conductor is "the term subordinated to the subject or its integral part that performs an action that is unique with the action of the subject itself", and the facilitator "the term subordinated to the subject that assists the subject to perform the action in any other way but not as a conductor" (1954, p. 51).
} 
3.1.1. The concept-organ in the sense of instrumentation is expressed by the analytical construction in function of accusatives, instrumentals and locatives, and it is lexicalized by various parts of the body: finger, hand, fist, paw, wing, leg, heel, stomach, face.

Analytical construction $n a+\mathrm{GC}$ in the fuction of the accusative $(2$ recorded examples):

\begin{tabular}{|c|c|c|c|c|}
\hline Podignem & & malo & na & prsti. \\
\hline $\begin{array}{l}\text { lift-1SG.PRS } \\
\text { "I lift mvself }\end{array}$ & $\begin{array}{l}\text { REFL } \\
\text { ttle on }\end{array}$ & $\begin{array}{l}\text { little-ADV } \\
\text { my toes “" }\end{array}$ & on & toe- GC.PL \\
\hline
\end{tabular}

Analytical construction $s(a)+\mathrm{GC}$ in the fuction of the instrumental (18 recorded examples):

$$
\begin{aligned}
& S \text { prst samo pomeraš. } \\
& \text { With finger-GC.SG just-ADV move-2SG. PRS } \\
& \text { "You just move with a finger." }
\end{aligned}
$$

Analytical construction $n a+\mathrm{GC}$ in the fuction of the locative ( 2 recorded examples):

$$
\begin{array}{llll}
\text { Malo } & n a & \text { prstić } i & \text { hodamo. } \\
\text { Little-ADV } & \text { on } & \text { toe-GC.PL } & \text { walk-1PL.PRS }
\end{array}
$$

"We walk on toes a little. "

3.1.2. The concept-object in the meaning of instrumentation is expressed by the analytical constructions in fuction of genitives, instrumentals and locatives with a tendency to penetrate the flective form. Different objects, means of transport, shoes, clothes, terms from modern technology and internet communication and necessary materials appear in the service of instruments in the realization of verbal action.

Analytical construction $s(a)+\mathrm{GC}$ in the fuction of the instrumental (21 recorded examples):

$$
\begin{array}{llll}
\text { Zalepio je } & \text { plakate } & \text { sa } & \text { lepak. } \\
\text { stick-3SG. M.PST } & \text { poster-ACC/GC.PL } & \text { with } & \text { glue-GC.SG }
\end{array}
$$

"He stuck the posters with glue."

Standard non-prepositional instrumental (5 recorded examples):
$\mathrm{Ja}$
crtam
obično
hemiskom.
I-NOM.SG draw-1SG.PRS usually-ADV with ballpiont pen-INS.SG

"I usually draw with a ballpiont pen. "

There are 18 examples with the verb to play in an analytical form while there is only one recorded example with the standard instrumental form:

Analytical construction $s(a)+\mathrm{GC}$ in the function of the instrumental:

$$
\begin{array}{lll}
\text { Igrali smo se } & \text { sa } & \text { konjići. } \\
\text { play-1PL.PST } & \text { with little toy horse-GC.PL } \\
\text { "We played with little toy horses. " }
\end{array}
$$

Standard non-prepositional instrumental:

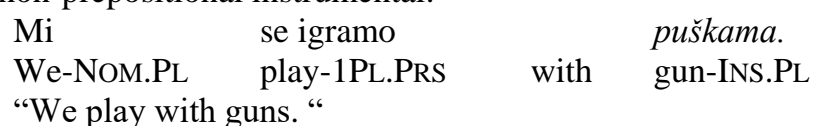

The preposition $s(a)$ is used with the standard instrumental form, which is the tendency observed by dialectologists in many folk speeches (Ivić, 1954, pp. 227-228). ${ }^{5}$

\footnotetext{
${ }^{4}$ This abbreviation we use when the general case is equal to the standard accusative case.
} 
Recorded examples of this type in the speech of children from Vranje were created in the process of hypercorrection ${ }^{6}$, all of which refer to the category of concept-object:

$\begin{array}{llll}\text { Juče } & \text { smo se igrali } & \text { sa } & \text { plastelinom. } \\ \text { yesterday-ADV } & \text { play-1PL.PST } & \text { with } & \text { modeling clay-INS.SG. } \\ \text { "Yesterday we played with modeling clay. " } & \end{array}$

The construction with the preposition $s(a)$ used with verbs to dive, to swim has the meaning of the facilitator, the supporting means in doing a verbal action $(6$ recorded examples $^{17}$ :

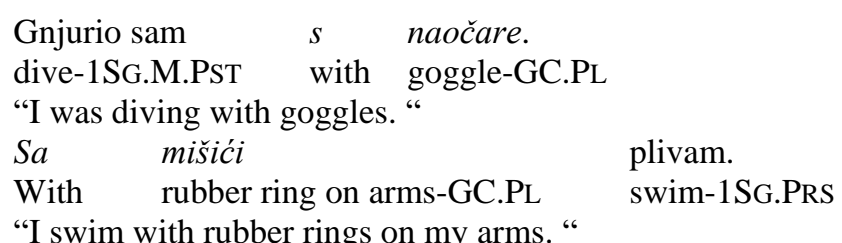

The analytical construction with the preposition $n a$ ( 8 recorded examples) and $u$ (8 recorded examples) is used in the function of the locative:

$\begin{array}{llll}\mathrm{Mi} \quad \text { igramo } & \text { na } & \text { mali } & \text { golovi. } \\ \text { We-Nom.PL play-1PL.PRS } & \text { on } & \text { small-GC.PL } & \text { goal-GC.PL } \\ \text { "We play on small goals. " } & & \\ U \quad \text { flašicu } & \text { čuva } & \text { pesak. } \\ \text { in bottle-GC.SG keep-3SG.PRS } & \text { sand ACC/GC.SG } \\ \text { "He keeps sand in a bottle. c8 } & \end{array}$

There are numerous constructions with lexemes that denote transport means. ${ }^{9}$ This meaning is expressed by the analytical constructions in function of instrumentals and locatives. The infiltration of flective form was recorded, too.

Analytical construction $s(a)+\mathrm{GC}$ in the function of the instrumental (21 recorded examples):

$\begin{array}{lll}\text { Idemo } & s & \text { autobus. } \\ \text { go-1PL.PRS by } & \text { bus-GC.SG } \\ \text { "We go by bus. " } & \end{array}$

Standard non-prepositional instrumental (8 recorded examples):

$\begin{array}{lll}\text { On } & \text { je došao } & \text { autobusom. } \\ \text { he-NOM.SG } & \text { come-3SG.M.PST by } & \text { bus-INS.SG }\end{array}$

"He came by bus."

\footnotetext{
${ }^{5}$ The expansion of the social structure at the expense of instrumental means Stevanović is explained by the influence of the neighbouring Western European languages, primarily Italian and German (1984-1985, p. 738), while M. Ivić believes that this phenomenon is a "natural further development of a process that is in progress from the earliest epoch of the Serbo-Croatian language" and that the foreign influence only accelerated this process (1954, pp. 231-232).

${ }^{6}$ Under the term hypercorrection: "a wrong or irregular pronunciation or form that has been reconstructed with the intention of replacing one condition, which is considered irregular, by a condition which is considered to be correct" (Simeon, 1969, pp. 475-476).

${ }^{7}$ Ivić cites the following verbs that appear with the facilitators: to drink, to get, to receive, to send, to report, to swim, to sail, to construct, to build, to make, to buy, to pay (1954, pp. 10-30).

${ }^{8}$ Among the mentioned examples, there are also those with the meanings that developed through the local meaning, which states S. Miloradović: "nouns with the meaning of a given entity (often a container) in which is the object over which the action expressed by a verb is done“(2003, pp. 254-255).

${ }^{9}$ Examples of this type are recorded by S. Miloradović in the speech of Paraćin Pomoravlje (2003, p. 202, p. 255).
} 
Analytical construction $u+\mathrm{GC}$ in the fuction of locative (12 recorded examples):

$$
\begin{aligned}
& U \text { tramvaj nisam se vozio. } \\
& \text { in tramb-GC.SG not ride-1SG.M.PST.NEG } \\
& \text { "I didn't ride in a tramb." }
\end{aligned}
$$

Standard construction $u+$ LOC (1 recorded example):

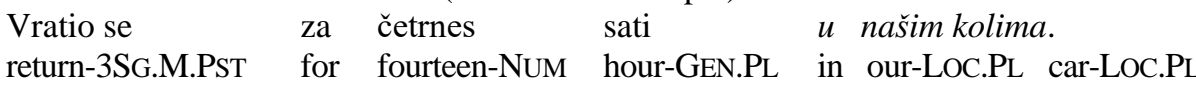

"He returned for fourteen hours in an ambulance car. "

There is always the general case with the preposition na (11 recorded examples):

$$
\begin{aligned}
& \text { Sankala sam se na sanke. } \\
& \text { ride-1SG.F.PST on sledge-GC.PL } \\
& \text { "I was riding on a sledge. " }
\end{aligned}
$$

The concept-object can be a lexeme in the meaning of footwear and clothing in the analytical construction with the proposition $u$ in the function of the locative ( 9 recorded examples) ${ }^{10}$ :

$$
\begin{array}{llll}
\begin{array}{l}
\text { Negde } \\
\text { somewhere-ADV }
\end{array} & \text { ide } & u & \text { mantil. } \\
\text { "He goes somewhere in his coat. " } & & \text { in } & \text { coat-GC.SG }
\end{array}
$$

Foreign language lexemes which denote terms from modern technology and the Internet communication have been used with the preposition pomoću and preko in the analytical construction in the function of the genitive and the preposition $n a$ in the analytical construction in the function of the locative. Examples with standard case form were recorded in the speech of only two respondents.

Analytical construction pomoću $+\mathrm{GC}$ in the function of the genitive (1 recorded example):

$$
\begin{array}{lll}
\text { Radi } & \text { pomoću } & \text { laptop. } \\
\text { work-3SG. PRS } & \text { using } & \text { laptop-GC.SG }
\end{array}
$$

"He works using a laptop."

Analytical construction preko $+\mathrm{GC}$ in the function of the genitive (4 recorded examples):

$$
\begin{aligned}
& \text { One su se svađale } \quad \text { preko fejsbuk. } \\
& \text { They-Nom.PL fight-3PL.F.PST through Facebook-GC.SG } \\
& \text { "They were fighting with that friend through Facebook. " }
\end{aligned}
$$

Standard construction preko + GEN (1 recorded example):

$$
\begin{array}{lllll}
\text { Ja } & \text { sam } & \text { ovde } & \text { gledala } & \text { preko televizije. } \\
\text { I-NOM.SG } & \text { AUX } & \text { here-ADV } & \text { watch-1SG.F.PST } & \text { on television-GEN.SG }
\end{array}
$$

"I was watching on television here. "

Analytical construction $n a+$ GC in the fuction of the locative (15 recorded examples):

$\begin{array}{llll}\text { Igram } & \text { igricu } & \text { na } & \text { telefon. } \\ \text { play-1SG. PRS } & \text { game ACC/GC.SG } & \text { on } & \text { phone-GC.SG }\end{array}$

"I play the game on the phone."

Standard construction $n a+$ LOC (3 recorded example):

$\begin{array}{llll}\text { Gledam } & \text { je } & n a & \text { kompjuteru. } \\ \text { watch-1SG. PRS } & \text { it-CLITIC } & \text { on } & \text { computer-LOC.SG }\end{array}$

"I watch it on the computer."

\footnotetext{
${ }^{10}$ Examples of this type are recorded by S. Miloradović in the speech of Paraćin Pomoravlje (2003, p. 258).
} 
The lexeme phone in the function of the facilitator was used in analytical construction with the prepositions od and $n a$ and in the standard instrumental form.

Analytical construction od + GC (1 recorded examples):

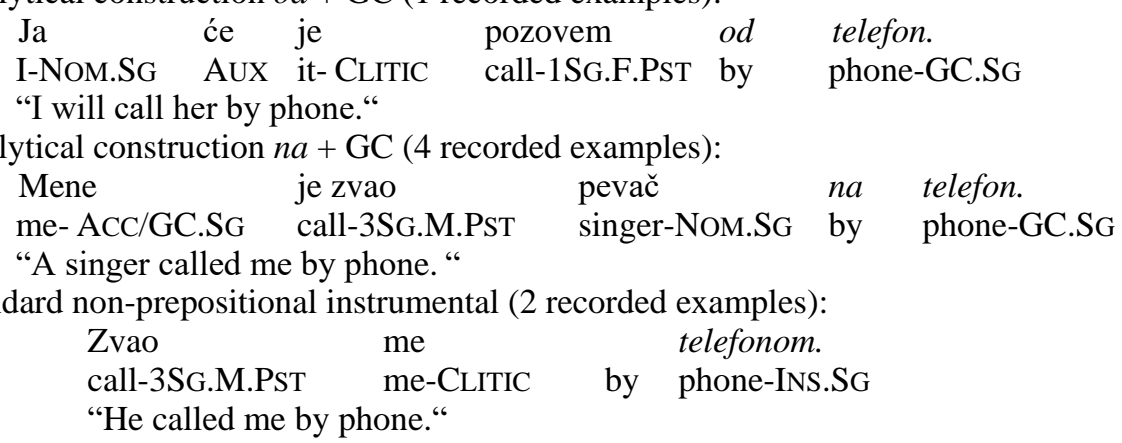

There were also recorded examples in which the concept-object represents the necessary material in the realization of determined action. This meaning is expressed by the analytical construction with the prepositions $s(a)$ in the fuction of the instrumental ( 2 recorded examples):

\begin{tabular}{|c|c|c|}
\hline SG. PRS & $\begin{array}{l}\text { ono } \\
\text { hing-ACC/GC.SG }\end{array}$ & \\
\hline
\end{tabular}

"I have the thing that is filled with sand. "

"The necessary material used for the realization of some kind of constructing action, with verbs like to build, to construct, to make, etc." in the function of the facilitator (Ivić, 1954: 22), is expressed with the analytical construction with the preposition $s(a)$ and $o d$ in function of instrumentals and genitives. Standard case form penetrates into the construction with the preposition $o d$.

Analytical construction $s(a)+\mathrm{GC}$ in the function of the instrumental (4 recorded examples):

$\begin{array}{lllll}\text { Ona } & \text { je pravila } & \text { saksiju } & \text { sa } & \text { glinu } \\ \text { she-Nom.Sg } & \text { make-3SG.F.PST } & \text { flower pot-ACC/GC.SG } & \text { from } & \text { clay-GC.SG }\end{array}$

"She made a flower pot from clay. "

Analytical construction $o d+\mathrm{GC}$ in the function of the genitive (14 recorded examples):

$$
\begin{array}{llll}
\text { Će pravimo } & \text { od } & \text { pesak } & \text { kulu. } \\
\text { make-1PL.FuT } & \text { from } & \text { sand-GC.SG } & \text { tower-ACC/GC.SG }
\end{array}
$$

"We will make a tower from sand. "

Standard construction od + GEN (7 recorded examples)
Napravili smo
lutku
od drvene
kašike.
make-1PL.PST doll-ACC/GC.SG from wooden-GEN.SG spoon- GEN.SG
"We made a doll from a wooden spoon."

3.1.3. The concept-animal in the meaning of instrumentation is expressed by the analytical construction with the preposition $s(a)$ and $n a$ in function of instrumentals and accusatives.

Analytical construction $s(a)+\mathrm{GC}$ in the function of the instrumental (3 recorded examples):

Spuštali se
descend-3PL.PST
"They descended with a horse. "


Analytical construction $n a+\mathrm{GC}$ in the function of the accusative (1 recorded example):

$\begin{array}{lll}\mathrm{Na} \quad \text { crvi } & \text { više } & \text { pecaju. } \\ \text { with worm-GC.PL more-ADV } & \text { angle-3PL.PRS } \\ \text { "They angle more with worms. " } & \end{array}$

3.1.4. Abstract nouns in the meaning of instrumentation are not inherent in children's speech. We record them in certain expressions and in conventional structures.

The preposition $n a$ in the analytical construction in the function of the locative was recorded in the expression to speak in a certain language, in the dialect (10 recorded examples):

$\begin{array}{lcccc}\text { Oni } & \text { govore } & n a & \text { drugi } & \text { jezik. } \\ \text { They-NOM.PL } & \text { speak-3PL.PRS in } & \text { another-GC.SG } & \text { language-GC.SG } \\ \text { "They speak in another language. " } & & & & \\ \text { Kući } & \text { pričam } & \text { na } & \text { vranjanski. } \\ \text { at home-ADV } & \text { speak-1SG.PRS } & \text { in } & \text { Vranje dialect-GC.SG } \\ \text { "I speak in Vranje dialect at home." } & & \end{array}$

The preposition preko in the standard genitive construction is recorded in a fixed expression over the contact:

$\begin{array}{llllll}\text { Tatko } & \mathrm{mu} & \text { će završi } & \text { sve } & \text { preko } & \text { veze. } \\ \text { daddy-Nom.SG } & \text { CLITIC } & \text { finish-3SG.FuT } & \text { it all } & \text { over } & \text { contact-GEN.SG }\end{array}$

"His daddy will finish it all over the contact. "

3.1.5. The concept-weather condition in which a verbal action is realized in the sense of the verbal action manner is expressed by the analytical construction with the preposition $n a$ in the function of the locative ${ }^{11}$ :

$\begin{array}{lll}\text { Idem na kišu. } & \\ \text { go-1SG.PRS in } & \text { rain-GC.SG } \\ \text { "I go in the rain. " } & \end{array}$

3.1.6. Prepositions for manner - the old forms of the instrumental case without preposition in the meaning of the verbal action manner (redom (by the order), kojim slučajem (by any chance), poreklom (by origin), jednom (once)) are recorded in a few examples.

\subsection{Mediativity}

Mediativity implies "indirect realization of the action of a determined predication" (Pavlović 2006, 209), that is, the realization of the action through an intermediary, an individual or an institution or organization. In the analyzed speech there are cases where the mediator of the action realization is the institution, the organization to which the person belongs - ballet, kindergarten, school, karate club, and excursion. ${ }^{12}$ This meaning

\footnotetext{
${ }^{11}$ In Normative grammar of Serbian language with this meaning we find the so-called situational locative with a preposition po: "Treniraju i po kiši i po snegu (They train both in rain and in the snow); Kros je održan po lepom vremenu (The cross was held in fine weather); Putovali smo po pravoj mećavi (They travelled in a real snowstorm)“ (Piper, Klajn, 2014, p. 366). In our material the normative rule by which the preposition on is used when it comes to the non-dynamic action was violated, and the preposition in when a dynamic action is in question (Petrović, 1968, p. 207).

${ }^{12} \mathrm{~S}$. Miloradović in the speech of Paraćin Pomoravlje records the locative construction with a preposition po for verbs follow, order and human being as a mediator (2003, pp. 272-273) and the genitive construction with a
} 
is expressed by the analytical construction with the preposition $s(a)$ in the function of the instrumental, only in one case the standard instrumental form was used:

Analytical construction $s(a)+\mathrm{GC}$ in the function of the instrumental (7 recorded examples):

$$
\begin{array}{lll}
\text { Ići ću } & \text { sa } & \text { školu. } \\
\text { go-1SG.FUT } & \text { with } & \text { school-GC.SG } \\
\text { "I'll go with school (group)." }
\end{array}
$$

Standard construction $s(a)+$ INS (1 recorded example):

$$
\begin{array}{llll}
\text { Bila sam na } & \text { Staroj } & \text { planini } & \text { sa vrtićem. } \\
\text { be-1SG.F.PST } & \text { on } & \text { Stara-LOC.SG planina-LOC.SG with kindergarten-INS.SG } \\
\text { "I was on Stara planina with the kindergarten (children).“ }
\end{array}
$$

\subsection{Comitivity}

Comitivity implies "indication of the presence or absence of a person, objects, events that follow the realization of the action and thus they determine it"(Pavlović, 2006, p. 218). In the traditional syntax, this meaning corresponds to the term accompanying circumstance, but with this term a person is not included, but only objects and phenomena.

In the analyzed speech, the meaning of comitivity is mainly expressed by the analitycal construction with the preposition $s(a)$ and bez in function of instrumentals and genitives. The penetration of the flective form is visible in both case structures. The analytical construction with preposition $u$ in the function of the locative is used with abstract nouns.

3.3.1. The meaning of the presence is expressed by the construction with the preposition $s(a)$ and a lexeme in the meaning of a human being, object, and rarely, a state ${ }^{13}$.

A human being in the constructions of this type implies an optional accomplice, and excludes the mutual effect of the equal performers of the act and a performer as a part of the group (Jurišić, 2014, p. 475). The analytical and the standard case forms were recorded in an almost equal number.

Analytical construction $s(a)+\mathrm{GC}$ in the function of the instrumental (21 recorded examples):

$$
\begin{aligned}
& \text { Putujev sa Deda Mraza. } \\
& \text { travel-3PL.PRS with Santa-GC.SG } \\
& \text { "They travel with Santa. " }
\end{aligned}
$$

Standard construction $s(a)+$ INS (28 recorded examples):

$$
\begin{array}{lllll}
\text { On } & \text { radi } & \text { sa } & \text { malom } & \text { decom. } \\
\text { He-Nom.SG } & \text { work-3SG.PRS } & \text { with } & \text { little-INS.SG } & \text { children-INS.SG } \\
\text { "He works with little children. " } & & &
\end{array}
$$

There is a significantly lower impact of the language standard when it comes to constructions with the name of object that follows the realization of a determined action:

preposition preko for the institution as a mediator (Ibid, p. 109). Similar examples are recorded by Jurišić in the speech of Gornja Pčinja (2014, p. 474). In our material there are no examples of this type.

${ }^{13}$ M. Ivić talks about the following instrumental, the instrumental of characteristic particularity and the component instrumental (1954, pp. 195-196). 
Analytical construction $s(a)+\mathrm{GC}$ in the function of the instrumental ( 8 recorded examples):

$$
\begin{array}{llll}
\text { Kad } & \text { sam ušo } & \text { sa } & \text { sok. } \\
\text { when-ADV } & \text { enter-1SG.M.PST } & \text { with } & \text { juice-GC.SG }
\end{array}
$$

"When I entered with juice."

Standard construction $s(a)+$ INS (1 recorded example):

$$
\begin{array}{llll}
\text { Ovde idu sa fenjerom. } & \text { sa } \\
\text { here-ADV go-3PL.PRS } & \text { with } & \text { lantern-INS.SG } \\
\text { "They go with the lantern here. " } &
\end{array}
$$

Generally, constructions with abstract nouns in the sense of comitivity are not characteristic of the analyzed speech. There are a few examples with the preposition $s(a)$ and the preposition $u$ in the analytical construction:

Analytical construction $s(a)+\mathrm{GC}$ in the function of the instrumental (1 recorded example):

$\begin{array}{lllll}\text { Sa } & \text { lakoću } & \text { će } & \text { gu } & \text { završim. } \\ \text { with } & \text { ease-GC.SG } & \text { AUX } & \text { it-CLiTIC } & \text { finish-1SG.F }\end{array}$

"I'll finish it with ease. "

Analytical construction $u+\mathrm{GC}$ in the function of the locative ( 2 recorded examples):

$\begin{array}{llll}\begin{array}{l}\text { Nekad } \\ \text { sometimes-ADV } \\ \text { "I say it for fun. " }\end{array} & \text { for } & \text { fun-GC.SG } & \text { kažem. }{ }^{14} \\ & & & \text { say-1SG.PRS }\end{array}$

3.3.2. The case construction with the preposition bez has the meaning of deprivation, absence, exclusion, separation of someone or something. Most recorded forms have an analytical form, while standard case form appears mainly in conventional expressions.

Analytical construction $b e z+\mathrm{GC}$ in the fuction of the genitive (19 recorded examples):

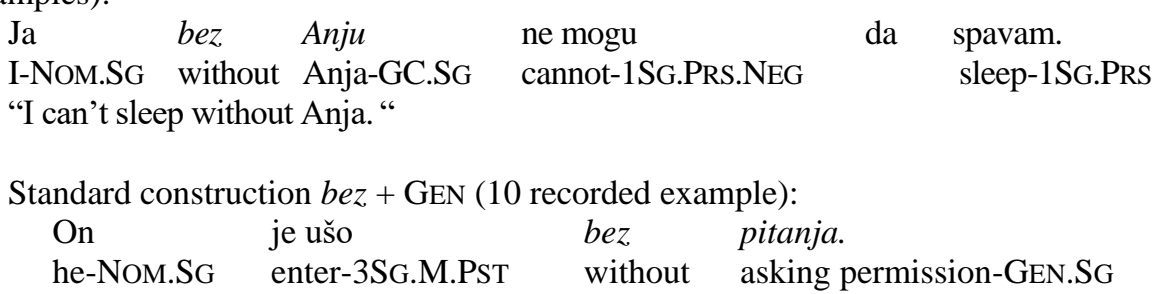

"He entered without asking permission. "

\subsection{Criteria}

The criteria implies "the identification of basis on which the realization of the directorial activity is based, or the framework by which this realization is modally limited“(Pavlović, 2006: 238). ${ }^{15}$

In the analyzed speech, this semantic category is expressed by the analytical construction with the preposition po in the function of the locative. The penetration of the flective case form is visible.

\footnotetext{
${ }^{14}$ In Normative grammar of Serbian language (2014) examples of this type belong to the category of situational locative (Piper, Klajn, 2014, pp. 365-366).

${ }^{15}$ In our linguistic literature this semantic category has a different status. More about this at Pavlović, 2006, p. 239.
} 
Analytical construction po $+\mathrm{GC}$ in the fuction of the locative (7 recorded examples):

$$
\begin{array}{llll}
\text { Prepoznajemo } & \text { ga } & \text { po } & \text { glas. } \\
\text { recognize-1PL.PRS him-CLITIC } & \text { by } & \text { voice-GC.SG } \\
\text { "We recognize him by voice. " } & &
\end{array}
$$

Standard construction po + LOC (4 recorded examples):

$$
\begin{array}{ll}
\text { Po debljini } & \text { se razlikuju. } \\
\text { by thickness-Loc.SG } & \text { differ-1PL.PRS } \\
\text { "They differ by thickness. " } &
\end{array}
$$

\subsection{Distributivity}

Distributivity implies ,form or formation in which a certain entity or object appears included in a directorial action"(Jurišić, 201, 478). ${ }^{16}$

In the analyzed speech, the significance of distributivity is expressed by the analytical construction with the preposition $n a$ in the function of the accusative (1 recorded example) and the analytical construction with the preposition $u$ in the function of the locative (1 recorded example):



In two examples, standard accusative form was used with the preposition $n a$ and number hundreds in the meaning of quantification:

$\begin{array}{llll}\mathrm{Na} & \text { stotine } & \text { kolača } & \text { pojela. } \\ \text { PREP } & \text { hundred-ACC.PL } & \text { of cake-GEN.PL } & \text { eat-3SG.F.PST }\end{array}$

"She ate hundreds of cakes."

\subsection{Comparability}

Comparability implies "qualifying the action of the predicate by bringing into connection that action with the same action of another agent, or the same agent, but in another period of time"(Pavlović, 2000, p. 100).

In the analyzed speech, this meaning is expressed with the construction od $+\mathrm{GC}$ in the function of the genitive. The penetration of the flective form is visible, too.

Analytical construction $o d+\mathrm{GC}$ in the function of the genitive (6 recorded examples):

$$
\begin{array}{llll}
\text { Učim manje } & \text { od } & \text { sestru. } \\
\text { study-1SG.PRS less-ADV } & \text { than } & \text { sister-GC.SG } \\
\text { "I study less than my sister." } & &
\end{array}
$$

Standard construction $o d+$ GEN (3 recorded examples):
Trči
brže
od mačke.
run-3SG.PRS faster-ADV
than cat-GEN.SG

"He runs faster than the cat."

\footnotetext{
${ }^{16}$ S. Pavlović considers distributivity and comparativity within the sociative-qualitative meaning (2000, pp. 98 101). In this paper, we consider these two categories independently according to the classification model given by M.Jurisić (2014, pp. 466-4789).
} 
The conducted analysis shows the dominantity of analytical constructions. The most stable analytical form is determined by the percentage analysis. Table 1 lists the number of recorded examples for each case construction and the percentage of the usage of the analytical construction for expression of adverbial qualification.

Table 1 The use of case constructions for expression of adverbial qualification

\begin{tabular}{lccc}
\hline Case function & $\begin{array}{c}\text { Analytical } \\
\text { Construction }\end{array}$ & $\begin{array}{c}\text { Standard } \\
\text { Construction }\end{array}$ & $\begin{array}{c}\text { Percentage of use of } \\
\text { analytical construction }\end{array}$ \\
\hline Genitive & 45 & 28 & 61.6 \\
Accusative & 6 & 2 & 75 \\
Instrumental & 128 & 46 & 73.6 \\
Locative & 90 & 8 & 91.8 \\
\hline
\end{tabular}

The analytical construction was confirmed in a number of examples for each case function. At the same time, it is the most stable in the function of locative $(91.8 \%)$, while the standard case form is the most intensively penetrating into the analytical construction in the function of the genitive - the percentage of the usage of the analytical construction in the function of the genitive is $61.6 \%$.

\section{CONCLUSION}

In the conditions of case analytism in the territory of Prizren-Timok speech zone, adverbial qualification in the speech of children from Vranje is expressed mostly by analytical structures in fuction of genitives, accusatives, instrumentals and locatives. They express the meaning of instrumentation, meditatively, comitivity, criteria, distributivity and comparatively. Nevertheless, the infiltration of standard case form has been recorded. Inventory of case constructions for expressing of adverbial qualification is given in Table 2.

Table 2 Inventory of case constructions for expressing of adverbial qualification

\begin{tabular}{|c|c|c|c|c|}
\hline Case meaning & Genitive & Accusative & Instrumental & Locative \\
\hline Instrumentation & $\begin{array}{c}\text { pomoću+GC } \\
\text { preko+GC / GEN } \\
\text { od+ GC / GEN }\end{array}$ & na+GC & $\begin{array}{l}\mathrm{s}(\mathrm{a})+\mathrm{GC} \\
\text { INS }\end{array}$ & $\begin{array}{c}\mathrm{na}+\mathrm{GC} / \mathrm{LOC} \\
\mathrm{u}+\mathrm{GC} / \mathrm{LOC}\end{array}$ \\
\hline Mediativity & I & I & $\mathrm{s}(\mathrm{a})+\mathrm{GC} / \mathrm{INS}$ & I \\
\hline Comitivity & bez+ GC / GEN & / & $\mathrm{s}(\mathrm{a})+\mathrm{GC} / \mathrm{INS}$ & $\mathrm{u}+\mathrm{GC}$ \\
\hline Criteria & / & l & / & po+GC / LoC \\
\hline Distributivity & I & $\mathrm{na}+\mathrm{GC} / \mathrm{ACC}$ & I & $\mathrm{u}+\mathrm{GC}$ \\
\hline Comparativity & od+ GC / GEN & l & I & I \\
\hline
\end{tabular}

The meaning of instrumentation is expressed in most cases by the analytical construction in function of genitives, accusatives, instrumentals and locatives.with prepositions $c(a), \mu a, y$, помоћу, преко, од. The most productive analytical structure is $s(a)+\mathrm{GC}$. The standard nonprepositional instrumental appears as a competing form to a construction with the preposition $s(a)$ and the concept-object in the meaning of the instrument. 
The meaning of meditatively is expressed by constructions with lexemes in the meaning of the institution, the organization to which the person belongs: ballet, kindergarten, karate club, school, and excursion. This meaning is expressed by the analytical construction in the function of the instrumental with the preposition $s(a)$. The standard language instrumental case was used in only one example...

The meaning of comitivity is expressed by the case construction with the preposition $s$ (a), bez, $u$ and lexemes in the meaning of a human being, object, and an abstract noun. Recorded case constructions with the preposition $s(a)$ and the preposition bez show the greatest exposure to the language standard - in almost equal number the analytical and standard case forms are present. Standard language constructions with the preposition bez generally represent conventional expressions.

The meaning of criteria is expressed by the analytical construction with the preposition po in the function of the locative.

The meaning of distributivity is expressed by the analytical construction with the preposition $n a$ in the function of the accusative and by the analytical construction with the preposition $u$ in the function of the locative. A flective case form was recorded in a construction with the preposition $n a$ and a number hundreds.

The meaning of comparatively is expressed by the comparative construction with the preposition $o d$ in the function of the genitive. The flective form penetrates into the genitive structure.

However, under the influence of standard language, the infiltration of flective form was recorded. The standard case form influences most intensively on the analytic construction in the function of the genitive. On the other hand, the construction in the function of locative is more resistant to the influence of linguistic standard.

The conducted analysis shows that the standard language form penetrates most intensively into the:

- genitive construction with the preposition od in the meaning of comitivity,

- genitive construction with the preposition od with lexemes in the sense of material, matter,

- genitive construction with the preposition od in the meaning of comparativity.

- instrumental construction with the preposition $s(a)$ in the meaning of comitivity,

- instrumental construction with the meaning of instrumentation,

- locative construction with the preposition po in the meaning of criteria

The adoption of the standard declension system in the teaching of Serbian grammar in Prizren-Timok speaking area needs to be approached in a special way. It is necessary to apply special procedures, methods and forms of work in teaching the case from the very beginning of working with students. The successful adoption of the standard case form can be contributed by a greater number of classes of case processing and a greater number of speech exercises aimed at practicing case forms. In older grades of elementary school, case forms can be practiced in the work of the language section and by linguistic analysis of literary works written on the dialect. As the analytical form in the function of the locative is very stable, in processing the declension system the most attention should be paid to the locative. In dialect environments whose grammatical system is very different from the standard, more work must be done to improve language culture through the teaching of the Serbian language. This was demonstrated by an analysis of expressing the meaning of adverbial qualification in the speech of preschool and elementary school children from Vranje. 
Acknowledgement: The paper presents a part of the research carried out during the preparation of the doctoral dissertation entitled The Speech of the Vranje's Children Preschool and School Age - sociolinguistic approach.

\section{REFERENCES}

Belić, A. (1999). Dijalekti istočne i južne Srbije. Beograd: Zavod za udžbenike i nastavna sredstva

Ivić, M. (1954). Značenja srpskohrvatskog instrumentala i njihov razvoj. Beograd: SANU.

Ivić, I. (2008). Počeci simboličke funkcije kod dece. In T. Ristić (Ed.), Metodika razvoja govora, Izabrani tekstovi (pp. 33-39). Jagodina: Pedagoški fakultet.

Janjić, M. (2004). Nastava padeža u osnovnim školama prizrensko-timočkog dijalekta. Književnost i jezik, LI/3$4,407-425$.

Janjić, M. (2005a). Nastava padeža u teoriji i praksi. Vranje: Učiteljski fakultet;Vranje: Aurora.

Janjić, M. (2005b). Neki problemi u vezi sa nastavnim interpretacijama akuzativa i lokativa u osnovnim školama na dijalekatskom području. Srpski jezik, X(1-2), 629-637.

Janjić, M. (2009). Padežni sistem na dijalekatskom području. In: R. Žugić (Ed.), Naučni skup: Dijalekat dijalekatska književnost (pp. 69-77). Leskovac: Leskovački kulturni centar.

Jocić, M. (2006). Jezik, komunikacija, razvoj. Novi Sad: Dnevnik - Novine i časopisi.

Jurišić, M. (2014). Sintaksa padeža Gornje Pčinje. Srpski dijalektološki zbornik. LXI, 373-533.

Kosić, Đ., i Vladisavljević, S. (2008). Pojava padeža. U: T. Ristić (Ed.), Metodika razvoja govora, Izabrani tekstovi (pp.133-139). Jagodina: Pedagoški fakultet.

Miloradović, S. (2003). Upotreba padežnih oblika u govoru Paraćinskog Pomoravlja: balkanistički $i$ etnomigracioni aspekt. Beograd: Čigoja štampa.

Mladenović, R. (1997). Padežne dinstikcije u govorima Šarplaninske oblasti. U: M. Pantić (Ed.), Naučni skup: Dani srpskog duhovnog preobraženja IV. O srpskim narodnim govorima (pp. 141-154). Despotovac: Narodna biblioteka „Resavska škola“.

Mladenović, R. (2002). Genitiv imenskih reči u severnošarplaninskim i južnometohijskim govorima - fleksija i analitizacija. Zbornik Matice srpske za filologiju i lingvistiku, XLV/1-2, 291-320.

Mladenović, R. (2004). O nekim padežnim konstrukcijama mesnog značenja sa višeznačnim predlozima u južnometohijskim i severnošarplaninskim govorima. Srpski jezik, IX/1-2, 193-210.

Mladenović, R. (2012). Fleksija i analitizam imenica na -a u govoru južnokosovskog sela Gatnje. Južnoslovenski filolog, LXVIII, $27-47$.

Mladenović, R. (2013). Predlozi vremenskog značenja pred i pre u prizrensko-južnomoravskim govorima metohijsko-kosovsko-sirinićkog areala. U: M. Kovačević (Ed.), Srpski jezik, književnost i umetnost, Knjiga I: Tradicija i inovacija u savremenom srpskom jeziku (pp. 91-99). Kragujevac: Filološko-umetnički fakultet.

Mladenović, R. (2014). Perlativni predlozi niz, uz, kroz u govorima jugozapadnog dela Kosova i Metohije u širem balkanskom prostoru. U: M. Kovačević (Ed.), Srpski jezik, književnost i umetnost, Knjiga I: Višeznačnost u jeziku (pp. 201-227). Kragujevac: Filološko-umetnički fakultet.

Pavlović, S. (2000). Determinativni padeži u govoru severozapadne Boke. Beograd: Institut za srpski jezik SANU.

Pavlović, S. (2006). Determinativni padeži u starosrpskoj poslovnopravnoj pismenosti. Novi Sad: Matica srpska.

Petrović, D. (1968). Upotreba padeža u jeziku Petra Kočića. Godišnjak Filozofskog fakulteta u Novom Sadu, $X I / 1,179-213$.

Piper, P. i drugi (2005). Sintaksa savremenog srpskog jezika: prosta rečenica. Beograd: Institut za srpski jezik SANU, Beogradska knjiga / Novi Sad: Matica srpska.

Piper, P. i Klajn, I. (2014). Normativna gramatika srpskog jezika. Novi Sad: Matica srpska.

Simeon, R. (1969). Enciklopedijski rječnik lingvističkih naziva. Zagreb: Matica hrvatska

Sobolev, A. (1988). О некаторых инновационных процессах в сфере выражения пространственых значение в территориальных диалектах сербохорватского языка. Zbornik Matice srpske za filologiju i lingvistiku, XXXI/1, 47-77.

Sobolev, A. (1990). Заметки о падежных системах сербохрватских говоров контактных зон. Južnoslovenski filolog, XLVI, 13-28.

Sobolev, А. (1991a). Категория падежа на периферии балканскославянского ареала. Zbornik Matice srpske za filologiju i lingvistiku, XXXIV/1, 93-139.

Sobolev, А. (1991b). К истории утраты балканскославянского склонения. Zbornik Matice srpske za filologiju i lingvistiku, XXXIV/2, 7-41.

Stevanović, M. (1984-1985). Socijativ-instrumental: jednakost i razlike, dodiri i mešanja. Zbornik Matice srpske za filologiju i lingvistiku, XXVII-XXVIII, 733-740. 
Stanković, D. (2018). Speech of preschool children and elementary school students from Vranje from the standpoint of urban dialectology. Facta Universitatis, Series: Teaching, Learning and Teacher Education, 2(1), 59-70.

Topolinjska, Z. (2001). Izražavanje padežnih odnosa u srpskom prizrenskom govoru. Zbornik Matice srpske za filologiju i lingvistiku, XLIV/1-2, 2112-24.

Topolinjska, Z. (2002). Antropocentrična teorija jezika i srpski padežni sistem. Južnoslovenski filolog, LVIII, 1-13.

Žugić, R. (2010). Iskazivanje genitivnih značenja u govoru jablaničkog kraja (u svetlu prizrensko-timočkih govora kao celine). Beograd: Institut za srpski jezik SANU / Čigoja štampa.

Žugić, R. (2012). Neke odlike pisane jezičke kulture studenata na prizrensko-timočkom dijalekatskom području (na primerima sintakse padeža i sintakse rečenice). Naše stvaranje, LIX/3-4, 265-275.

Žugić, R. (2013). Upotreba padeža u pisanom izražavanju studenata na području prizrensko-timočkog dijalekta, Zbornik radova Filozofskog fakulteta u Prištini, XLIII/2, 511-528.

\section{IZRAŽAVANJE ADVERBIJALNE KVALIFIKATIVNOSTI U GOVORU VRANJSKE DECE PREDŠKOLSKOG I OSNOVNOŠKOLSKOG UZRASTA}

U radu su analizirane padežne konstrukcije kojima vranjska deca predškolskog i osnovnoškolskog uzrasta izražavaju adverbijalnu kvalifikativnost. Cilj rada je da se opišu sve padežne konstrukcije sa značenjem adverbijalne kvalifikativnosti $i$ utvrdi u koje padežne konstrukcije flektivni padežni oblik najlakše prodire. Analiziran je govor 40 ispitanika različitog uzrasta, pola, mesta stanovanja, obrazovanja roditelja. Građa je prikupljena metodom spontanog razgovora. Deskriptivnom metodom su date osnovne karakteristike ispitivane osobine, analizirani su i opisani svi zabeleženi padežni oblici, a procentualnom analizom je utvrđena najstabilnija analiticka forma. Sprovedena analiza je pokazala da značenje adverbijalne kvalifikativnosti deca predškolskog i osnovnoškolskog uzrasta iz Vranja izražavaju uglavnom analitičkom konstrukcijom u funkciji genitiva, akuzativa, instrumentala i lokativa. Njima je izraženo značenje instrumentativnosti, medijativnosti, komitativnosti, kriterija, distributivnosti $i$ komparativnosti. Ipak, pod uticajem standardnog jezika, zabeležen je prodor flektivne forme. Standardnojezička forma najintenzivnije prodire u analitičku konstrukciju u funkciji genitiva. Na drugoj strani, najotpornija na uticaj jezičkog standarda jeste analitička konstrukcija u funkciji lokativa. S obzirom na to da je proučavanje dijalekatske sintakse padeža i govora dece retkost u dijalektološkim istraživanjima, sprovedeno istraživanje je opravdano i značajno kako za dalja istraživanja dijalekatske sintakse, tako i za nastavu srpskog jezika na prizrensko-timočkom govornom području.

Ključne reči: adverbijalna kvalifikativnost, govor vranjske dece, deklinacija, analitizam, standardnojezički oblik. 